\title{
CELL-FREE SYNTHESIS OF THE DEPSIPEPTIDE BEAUVERICIN
}

\author{
Hugo Peeters*, Rainer Zocher, Norbert Madry, Peter B. Oelrichi', \\ Horst Kleinkauf and Gunda Kraepelin \\ Institut für Biochemie und Molekulare Biologie \\ der Technischen Universität Berlin \\ Franklinstraße 29, D-1000 Berlin 10, FRG \\ ${ }^{+}$Animal Research Institute, Yeerongpilly, Q., Australia
}

(Received for publication July 27, 1983)

\begin{abstract}
The enzymatic formation of the cyclodepsipeptide beauvericin was demonstrated in cellfree extracts from Beauveria bassiana. In analogy to the enniatin synthetase system formation of beauvericin is strictly dependent on the presence of the constituent amino and hydroxy acid, $S$-adenosylmethionine, and ATP $/ \mathrm{Mg}^{2+}$.

Synthesizing activity could be enriched about 12-fold by fractional ammonium sulfate precipitation. Besides the enniatin synthetase system this represents another example of the cell-free synthesis of a depsipeptide from eucaryotic origin.
\end{abstract}

Beauvericin is a cyclodepsipeptide with insecticidal properties produced by certain strains of the fungi Beauveria bassiana and Paecilomyces fumosoroseus ${ }^{1,2,3)}$. It is composed of three residues each of $\mathrm{N}$-methyl-L-phenylalanine (MePhe) and D-2-hydroxyisovaleric acid (HYIV), and thus may be regarded as a homologue of the ionophoric antibiotics enniatin $\mathrm{A} \sim \mathrm{C}$ (Fig. 1).

The biosynthesis of the enniatins has already been elucidated ${ }^{4}$. The multienzyme, enniatin synthetase, catalyzes the formation of the depsipeptide in the presence of the substrate amino acids and D-2-hydroxyisovaleric acid, $S$-adenosylmethionine (SAM) and ATP, involving several activation, me-

Fig. 1.

Beauvericin, $\mathrm{R}=-\mathrm{CH}_{2} \mathrm{C}_{6} \mathrm{H}_{5}$; Enniatin $\mathrm{A}, \mathrm{R}=$ $-\mathrm{CH}\left(\mathrm{CH}_{3}\right) \mathrm{CH}_{2} \mathrm{CH}_{3}$; Enniatin B, $\mathrm{R}=-\mathrm{CH}\left(\mathrm{CH}_{3}\right)_{2}$; Enniatin $\mathrm{C}, \mathrm{R}=-\mathrm{CH}_{2} \mathrm{CH}\left(\mathrm{CH}_{3}\right)_{2}$.

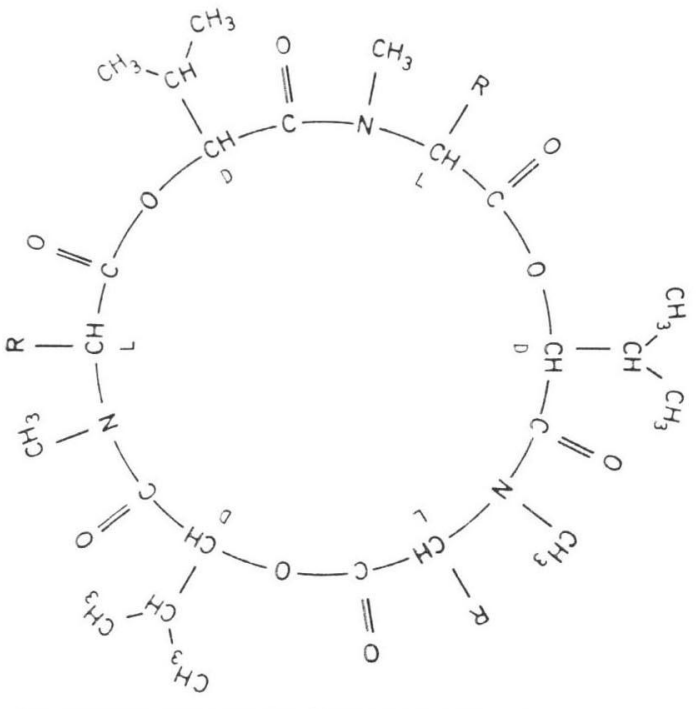
thylation and condensation reactions, similar to the non-ribosomal formation of peptide antibiotics like gramicidin $\mathrm{S}^{5)}$.

In view of the close structural relationship between beauvericin and the enniatins we wondered whether the biosynthesis of beauvericin might also proceed in a manner similar to enniatin biosynthesis. A preliminary study providing ${ }^{14} \mathrm{C}$-labelled precursors in vivo to $P$. fumosoroseus indicated such a similarity ${ }^{\mathrm{e}}$.

In this publication we describe the formation of beauvericin in vitro by cell-free extracts of B. bassiana.

\section{Materials and Methods}

Chemicals and Radioisotopes

Radioactive DL-HYIV and unlabelled DHYIV were prepared from DL-[1- $\left.{ }^{14} \mathrm{C}\right]$ valine

* To whom correspondence should be addressed. 
(specific activity: $60 \mathrm{Ci} / \mathrm{mol}$ ) and $\mathrm{D}$-valine, respectively, by reaction with $\mathrm{HNO}_{2}{ }^{7 \text { ) }}$. Specific activity of $\mathrm{L}-\left[U_{-}{ }^{14} \mathrm{C}\right]$ phenylalanine was $513 \mathrm{Ci} / \mathrm{mol}$. Radioactive compounds were purchased from Amersham. All other reagents were of highest purity commercially available.

\section{Organism and Growth Conditions}

The fungus identified as B. bassiana (Bals.) Vuill. was isolated from living larvae of the Australian sawfly Lophyrotoma cyanea (Pterigophorinae) feeding on Eucalyptus melanophloia. It was grown on agar slants ( $3 \%$ molasses, $1 \%$ cornsteep liquor, $2 \%$ agar) for $10 \sim 12$ days. Spore suspensions $\left(10^{3}\right.$ spores $/ \mathrm{ml}$ ) were prepared by filtration of a suspension of slant surface growth in sterile water. Submerged cultivation was carried out as described ${ }^{e)}$. An inoculum of $10^{7}$ spores per flask containing $100 \mathrm{ml}$ cornsteep - molasses medium was used. $\left.{ }^{[14} \mathrm{C}\right]$ Phenylalanine incorporation into beauvericin in vivo was measured as described ${ }^{8)}$. The cultures were harvested by suction filtration about 50 hours after inoculation (time of maximum in vivo incorporation). The mycelial cake was washed with $0.3 \mathrm{M} \mathrm{KCl}$ and stored at $-80^{\circ} \mathrm{C}$.

\section{Preparation of Cell-free Extracts}

All operations were carried out at $4^{\circ} \mathrm{C}$. Buffers: Buffer B, 50 mm potassium phosphate ( $\left.\mathrm{pH} 7.0\right)$, $4 \mathrm{~mm}$ dithiothreitol, $0.25 \mathrm{~mm}$ EDTA; Buffer A, $0.3 \mathrm{M} \mathrm{KCl}$ in Buffer B.

\section{Crude Extract}

Lyophilized mycelium (1 2 g) was homogenized with quartz sand in a mortar and extracted with $20 \mathrm{ml}$ buffer A per gram dry weight. After 20 minutes of gentle stirring the homogenate was centrifuged for 15 minutes at $2,5000 \times g$.

Poly(ethyleneimine) (PEI) precipitation ${ }^{8)}$

A neutral solution of Polymin P (BASF, Ludwigshafen, FRG) $(5 \%)$ was added to give a final concentration of $0.1 \%$. After 20 minutes the extract was centrifuged as described above.

Ammonium Sulfate Precipitation

Saturated ammonium sulfate solution in buffer B was gradually added to the supernatant. Precipitates were pelleted by centrifugation $(10$ minutes $20,000 \times g)$. The precipitate between 25 and $35 \%$ saturation was dissolved in a minimal volume of buffer B and desalted by passage through a small Ultrogel AcA 44 column previously equilibrated with buffer B.

\section{Assay of Beauvericin - Synthesizing Activity in Cell-free Extracts}

The assay mixture contained ATP (4 mM), $\mathrm{Mg}(\mathrm{OAc})_{2}$ (4 mM), HYIV (0.2 mM), SAM (0.2 mM) and $0.5 \mu \mathrm{Ci} \mathrm{L}-\left[{ }^{14} \mathrm{C}\right]$ phenylalanine in a total volume of $120 \mu \mathrm{l}$. After incubation for 10 minutes at $25^{\circ} \mathrm{C}$, $2 \mathrm{ml}$ each of $\mathrm{H}_{2} \mathrm{O}$ and EtOAc were added to the assay mixture.

EtOAc-extractable compounds were separated by TLC on silica gel (authentic beauvericin was added as a carrier) (Merck Kieselgel 60, EtOAc - $\mathrm{MeOH}-\mathrm{H}_{2} \mathrm{O}, 100: 5: 1$ ).

After visualisation of the beauvericin bands by iodine vapor, they were scraped off the plates and the antibiotic was eluted twice with $2 \mathrm{ml}$ EtOAc. Radioactivity of the beauvericin bands was measured in a Packard Tri-Carb scintillation counter. The activity of the beauvericin-synthesizing system is either directly expressed as cpm or calculated from these data as pmol beauvericin formed taking into account the specific radioactivity of the labelled compounds applied and the counting efficiency.

Characterization of the products by two dimensional separation of acid hydrolysates was carried out as described earlier ${ }^{\mathrm{e})}$. Protein concentrations were measured by a modified Bradford procedure with bovine serum albumin (Serva, Heidelberg, FRG) as a standard ${ }^{9}$.

\section{Results and Discussion}

Cell-free extracts prepared from lyophilized mycelium of $B$. bassiana as described in "Materials and Methods" were able to synthesize beauvericin in vitro. Several other beauvericin-producing strains of $B$. bassiana (other isolates) and $P$. fumosoroseus, were found to be unsuitable sources for active cell-free 
Table 1. Partial purification of the beauvericin synthesizing activity. $3.4 \mathrm{~g}$ of lyophilized mycelium were the starting material.

\begin{tabular}{lccccc}
\hline \multicolumn{1}{c}{$\begin{array}{c}\text { Purification } \\
\text { step }\end{array}$} & $\begin{array}{c}\text { Volume } \\
(\mathrm{ml})\end{array}$ & $\begin{array}{c}\text { Protein } \\
\text { total }(\mathrm{mg})\end{array}$ & $\begin{array}{c}\text { Total } \\
\text { units* }\end{array}$ & $\begin{array}{c}\text { Specific } \\
\text { activity } \\
\text { (units/mg) }\end{array}$ & $\begin{array}{c}\text { Recovery } \\
(\%)\end{array}$ \\
\hline Crude extract & 88.0 & $1,214.0$ & 30.8 & 0.025 & 100 \\
PEI-precipitation & 85.0 & 892.5 & 26.5 & 0.029 & 86 \\
$\left(\mathrm{NH}_{4}\right)_{2} \mathrm{SO}_{4}$-precipitation & 5.5 & 77.5 & 24.9 & 0.321 & 80.8 \\
\hline
\end{tabular}

* 1 unit is defined as $1 \mathrm{pmol}$ beauvericin formed per second.

Fig. 2. In vitro formation of beauvericin.

Autoradiogram of a thin-layer chromatogram (see Materials and Methods). $100 \mu 1$ of enzyme (ammonium sulfate step) were incubated for 10 minutes at $25^{\circ} \mathrm{C}$ in the presence of: $\mathrm{A}:\left[{ }^{14} \mathrm{C}\right]$ HYIV, ATP $/ \mathrm{Mg}^{2+}$, Phe, SAM; B: $\left[{ }^{14} \mathrm{C}\right] \mathrm{HYIV}$, Phe, SAM; C: $\left[{ }^{14} \mathrm{C}\right]$ Phe, HYIV, SAM, ATP/ $\mathrm{Mg}^{2+}$; D: $\left[{ }^{14} \mathrm{C}\right] \mathrm{Phe}$, HYIV, SAM.

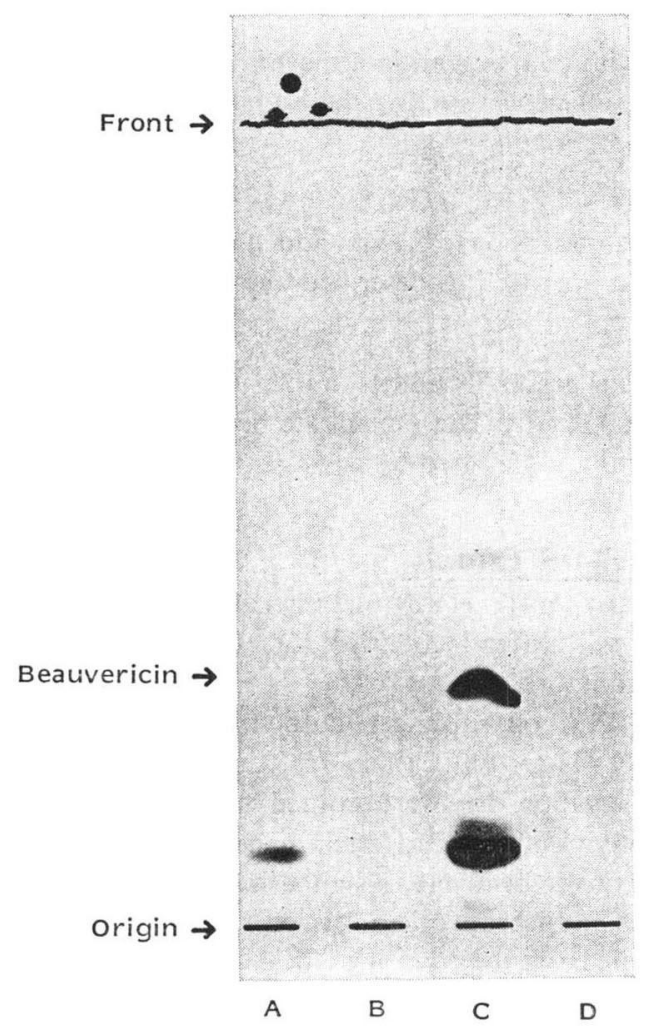

Table 2. Dependence of cell-free beauvericin synthesis on different substrates.

Assay conditions were as described in Materials and Methods with the exception of the indicated omission.

\begin{tabular}{lcc}
\hline Substrates & $\begin{array}{c}{\left[{ }^{14} \mathrm{C}\right] \mathrm{Phe}} \\
(\mathrm{cpm})\end{array}$ & $\begin{array}{c}{\left[{ }^{14} \mathrm{C}\right] \mathrm{HYIV}} \\
(\mathrm{cpm})\end{array}$ \\
\hline Complete & 56,558 & 15,963 \\
- ATP & 725 & 113 \\
- Mg & & 5,951 \\
- SAM & 11,992 & 96 \\
- HYIV & 512 & - \\
- Phe & 70 & 75 \\
\hline
\end{tabular}

Fig. 3. Time dependence of beauvericin formation (assay as described under Materials and Methods except that $130 \mu \mathrm{M}$ phenylalanine was used).

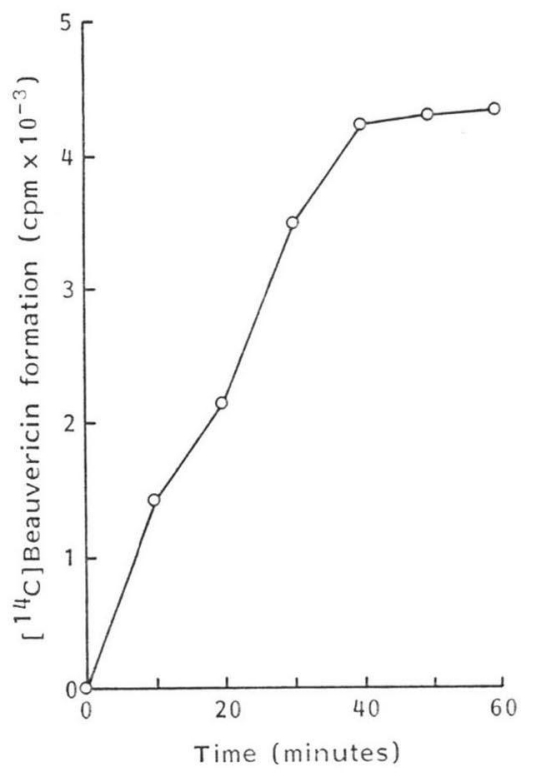

extracts. Incubation of cell-free extracts with L- $\left[{ }^{14} \mathrm{C}\right]$ phenylalanine or $\left[{ }^{14} \mathrm{C}\right] \mathrm{HYIV}$ in the presence of ATP, $\mathrm{Mg}^{2+}$, SAM, and unlabelled HYIV or phenylalanine, respectively, yielded radioactive beauvericin and other unidentified EtOAc-extractable compounds (Fig. 2). Alternatively, [methyl- $\left.{ }^{14} \mathrm{C}\right] \mathrm{SAM}$ could be used as the labeling substrate (not shown). In vitro beauvericin formation proceeded linearily for 
at least 30 minutes (Fig. 3).

The beauvericin synthesizing activity could be enriched about twelve-fold by subsequent PEI and ammonium sulfate precipitations (Table 1). The experiments described below were carried out with such partially purified preparations. There was no significant loss of activity when preparations obtained after the ammonium sulfate step were stored at $-80^{\circ} \mathrm{C}$ in buffer B containing $20 \%$ glycerol for several months.

In vitro product formation was absolutely dependent on ATP (see Fig. 3), HYIV, and L-phenylalanine (Table 2). Omission of $\mathrm{Mg}^{2+}$ resulted in a decrease of beauvericin formation by about $70 \%$ (Table 2). In an incubation mixture containing L- $\left[{ }^{14} \mathrm{C}\right]$ phenylalanine, HYIV, magnesium acetate, and ATP but not SAM, a new radioactive product with a lower $\mathrm{R} f$ value was formed instead of beauvericin (not shown), which was tentatively identified as unmethylated beauvericin. Acid hydrolysis of this compound yielded $\left[{ }^{14} \mathrm{C}\right]$ phenylalanine exclusively; no $\left[{ }^{14} \mathrm{C}\right] \mathrm{MePhe}$ could be detected. This result is analogous to that obtained with purified enniatin synthetase, which catalyzed the formation of unmethylated enniatin in the absence of $\mathrm{SAM}^{4}$.

As already shown by in vivo experiments with another fungus, $P$. fumosoroseus $^{()}$, free MePhe was not incorporated into the depsipeptide by active cell-free preparations from B. bassiana. Incubation of active preparations with $\left[{ }^{14} \mathrm{C}\right] \mathrm{HY}$ IV $, \mathrm{ATP}, \mathrm{Mg}^{2+}$, and $\mathrm{MePhe}$ did not yield any radioactive EtOAcextractable compounds. Presumably, $\mathrm{N}$-methylation is an obligatory intermediate step in beauvericin formation; only the unmethylated amino acid is accepted as a substrate for beauvericin synthesis. We conclude, that MePhe is not a free intermediate. Methylation of Phe residues is a later step in beauvericin synthesis occurring anywhere between amino acid binding to the hypothetical synthetase and release of the final product. In the case of enniatin biosynthesis, $N$-methylation of the amino acids only occurs after their activation as enzyme-bound thioesters ${ }^{10)}$.

In conclusion, the experiments reported demonstrate the cell-free formation of beauvericin. In addition to enniatin synthetase from Fusarium oxysporum the beauvericin system represents another example of depsipeptide synthesis in vitro. Further purification of the beauvericin-synthesizing activity is necessary to determine more closely whether the hypothetical "beauvericin synthetase" has additional features in common with enniatin synthetase.

\section{Acknowledgments}

We thank C. LoLaIT for her skillful technical assistance. The work was supported by the Deutsche Forschungsgemeinschaft (Sfb 9, Teilprojekt C 3). H. P. thanks the Erwin-Riesch-Stiftung Lorch, FRG for a fellowship.

\section{References}

1) Hamill, R. L.; C. E. Higgens, H. E. Boaz \& M. Gorman: The structure of beauvericin, a new depsipeptide antibiotic toxic to Artemia salina. Tetrahedron Lett. 1969: 4255 4258, 1969

2) Bernardini, M.; A. Carilli, G. Pacioni \& B. Santurbano: Isolation of beauvericin from Paecilomyces fumoso-roseus. Phytochemistry 14: 1865, 1975

3) Grove, J.F. \& M. Pople: The insecticidal activity of beauvericin and the enniatin complex. Mycopathologia 70: $103 \sim 105,1980$

4) Zocher, R.; U. Keller \& H. Kleinkauf: Enniatin synthetase, a novel type of multifunctional enzyme catalyzing depsipeptide synthesis in Fusarium oxysporum. Biochemistry 21: 43 48, 1982

5) Kleinkauf, H.: Antibiotic polypeptides - Biosynthesis on multifunctional protein templates. Planta Medica 35: $1 \sim 18,1979$ 
6) Peeters, H.; R. Zocher, N. Madry \& H. Kleinkauf: Incorporation of radioactive precursors into beauvericin produced by Paecilomyces fumoso-roseus. Phytochemistry 22: 1719 1720, 1983

7) Fischer, E. \& H. Scheibler: Zur Kenntniss der Waldenschen Umkehrung. III. Ber. Dtsch. Chem. Ges. 41: $2891 \sim 2902,1908$

8) VON DER HAAR, F.: Purification of proteins by fractional interfacial salting out on unsubstituted agarose gels. Biochem. Biophys. Res. Comm. 70: 1009 1013, 1976

9) BRADFORD, M. M.: A rapid and sensitive method for the quantitation of microgram quantities of protein utilizing the principle of protein-dye binding. Anal. Biochem. 72: 248 254, 1976

10) Zocher, R. \& H. Kleinkauf: Biosynthesis of enniatin B: Partial purification and characterization of the synthesizing enzyme and studies of the biosynthesis. Biochem. Biophys. Res. Comm. 81: 1162 1167, 1978 